\title{
Challenges To Efficient And Effective Irrigation Water Management In Ghana - The Case Of Bontanga Irrigation Project
}

\author{
Clifford A. Braimah ${ }^{1}$, Sampson Agodzo ${ }^{2}$, \\ 1. (Department of Agriculture Engineering, Tamale Polytechnic,P. O. Box 3 ER, Tamale, Ghana) \\ (Department of Agricultural Engineering, Kwame Nkrumah University of Science and Technology, \\ Kumasi, Ghana)
}

\begin{abstract}
Irrigation projects in Ghana have suffered from poor water management practices and this has been so because over the years irrigation system operation has been limited to construction of new projects and sometimes rehabilitation of existing ones. Post construction management of irrigation projects has not received the needed attention because adequate provisions in terms of manpower and resources are not made available to make that possible. There are always water flow measuring structures installed in irrigation projects but they are hardly used due to the sophisticated nature of measuring the flow of water using such structures. Water flow measuring devices installed on irrigation projects in Ghana are weirs and flumes. Calibrating such water flow devices will ensure the effective and efficient water management practices on those irrigation projects because the right quantities of water will be delivered to the fields from the water reservoirs. This research undertook a process of calibrating the two flumes on both the right bank and left bank canals of the Bontanga Irrigation Projects to ensure that the water levels in the canals can easily be converted into volumetric flow to allow for the water bailiffs to gauge the quantity of water being released into the canals. The relationship between the water level (h) in the canal and the discharge $(\mathrm{Q})$ for the right bank flume was determined as $\mathrm{Q}=4.425 \mathrm{~h}^{1.672}$ and that of the left bank canal was determined as $\mathrm{Q}=4.066 \mathrm{~h}^{1.775}$. The research also measured the average runoff and sediment deposition into the Bontanga Irrigation reservoir. As a function of rainfall $(\mathrm{P})$ the runoff $(\mathrm{R})$ in the catchment was established as $\mathrm{R}=0.16 \mathrm{P}$ and the annual sediment deposition around the right bank intake was $6.60 \mathrm{~cm}$ whilst that around the left bank intake was $6.35 \mathrm{~cm}$. It is recommended that effective and efficient water management practices must be stepped up on the Bontanga Irrigation project if the country wants to derive the needed benefits from the project.
\end{abstract}

Keywords: - Bontanga Irrigation Project, Water management, calibration

\section{INTRODUCTION}

Irrigation development in Ghana officially started in the early 1960s under the defunct Land Planning and Soil Conservation Unit of the Ministry of Agriculture and received a boost in 1977 under the Supreme Military Council (SMC) decree 85 which established the Irrigation Development Authority (IDA) wholly owned and financed by the Government of Ghana (MoFA, 2013). The Authority as established was to become responsible for identifying and in some cases involved in the management and maintenance of irrigation schemes in Ghana (MoFA, 2013). Currently there are about 50 Irrigation Projects and Schemes spread across Ghana and were constructed by the Irrigation Development Authority, spanning tens of thousands of hectares (MoFA, 2013). Meanwhile Irrigation potential for the country including valley bottoms and flood plains has been estimated to be in millions of hectares (Namara et al., 2010). This potential needs to be exploited further if Ghana is to become food sufficient and increase the economy to a middle income status by 2015 .

Irrigation in Ghana has been contributing significantly to the lives of many people especially in the areas of poverty alleviation, food security and general improvement in the quality of lives of those who are engaged in it and still has some huge potentials that could be exploited (Braimah, 2004; Kye-Baffour and Ofori, 2006; MoFA, 2011; Namara et al., 2010 ). However, the sustainability of irrigated projects worldwide is being questioned environmentally and economically (Gleick, 1992), the need therefore to sustainably managed the current irrigation projects and schemes in Ghana. The outputs of the Irrigation schemes and projects in Ghana have been considered not to be very encouraging and that some of these projects have been rendered unproductive due to the lack of maintenance (MoFA, 2013). Four major problems identified to be militating against the irrigation subsector in Ghana are: "low agricultural productivity and slow rates of growth, constrained socio-economic engagement with land and water resources, environmental degradation associated with irrigated production and lack of irrigation support services (MoFA, 2011). At some point in time lack of expertise was cited as another challenge to the growth of the irrigation development in Ghana and on most of the 
irrigation projects, utilization of the potential irrigable area has been considerably low (Kyei-Baffour and Ofori, 2006) as shown in Table 1 below. It is instructive to say that of the area developed for irrigation not all are being utilised for irrigation (Miyoshi, 2006) as shown in Table 2 below.

Table 1: Irrigation capacity utilisation of selected irrigation projects in Ghana

\begin{tabular}{lccc}
\hline Irrigation Project & $\begin{array}{c}\text { Irrigable Potential } \\
(\mathbf{H a})\end{array}$ & $\begin{array}{c}\text { Net Irrigated area } \\
(\mathbf{H a})\end{array}$ & $\begin{array}{c}\text { Capacity Utilisation } \\
(\boldsymbol{\%})\end{array}$ \\
\hline Afife & 1,021 & 800 & 79 \\
Akumadan & 810 & 65 & 8 \\
Asutsuare & 2,000 & 216 & 11 \\
Bontanga & 540 & 470 & 87 \\
Dawhenya & 486 & 191 & 39 \\
Nobewam & 215 & 40 & 19 \\
Tono & 2,632 & 800 & 28 \\
Vea & 1,417 & 400 & 28 \\
Weija & 2,267 & 220 & 10 \\
\hline
\end{tabular}

Source: Kyei-Baffour and Ofori (2006)

Table 2: Utilisation of irrigation fields on selected irrigation projects in Ghana

\begin{tabular}{lccc}
\hline $\begin{array}{l}\text { Irrigation } \\
\text { Project }\end{array}$ & $\begin{array}{c}\text { Irrigated Area } \\
(\mathbf{H a})\end{array}$ & $\begin{array}{c}\text { Area actually being } \\
\text { Irrigated (Ha) }\end{array}$ & $\begin{array}{c}\text { Capacity Utilisation } \\
(\%)\end{array}$ \\
\hline Ashaiman & 155 & 56 & 36 \\
Dawhenya & 200 & 150 & 75 \\
Weija & 220 & 0 & 0 \\
Kpong & 2,786 & 616 & 22 \\
Afife & 880 & 880 & 0 \\
Aveyeme & 60 & 0 & 52 \\
Okyereko & 81 & 42 & 0 \\
Akumadan & 65 & 0 & 0 \\
Anum Valley & 89 & 0 & 0 \\
Kikam & 27 & 0 & 0 \\
Amate & 101 & 0 & 15 \\
Kpando Torkor & 40 & 6 & 100 \\
Mankessim & 17 & 17 & 23 \\
Subinja & 60 & 6 & 71 \\
Tanoso & 64 & 15 & 40 \\
Sata & 34 & 24 & 87 \\
Dadieso & 20 & 8 & 40 \\
Bontanga & 450 & 390 & 100 \\
Golinga & 40 & 16 & 98 \\
Libga & 16 & 16 & 59 \\
Tono & 2,490 & 2,450 & \\
Vea & 850 & 500 & 0 \\
\hline
\end{tabular}

Source: Adapted from Miyoshi (2006)

Currently, irrigation projects in Ghana are confronted with some challenges that are water and facility management related, cause by factors such as lack of awareness of farmers' role in the management of the irrigation facilities and unskilled water management techniques (Miyoshi, 2006). Kyei-Baffour and Ofori (2006) have also cited water management as the drawback to the current irrigation schemes in Ghana and even farmers on the well developed and managed irrigation projects in some cases have considerer water supplied to their irrigation farms as inadequate and irregular (Dinye and Ayitio, 2013). This is making the case for effective and efficient water management on irrigation projects more important. The interest of farmers in water management practices on irrigation projects usually differ, depending on the perceived availability of water for irrigation. There is lack of interest in water management on irrigation projects with no water availability challenges as against the show of interest in managing reservoir water on projects with dwindling water in the reservoir (Faulkner, 2006). Even in the cases where there is show of interest to manage the dwindling water in the reservoir, it is done without any estimation of the quantity to supply. Effective water management on irrigation 
projects require measurements of crop water demand and quantity of water to be supplied and to make this possible it is said that water measuring devices must be provided (EPA, 2003).

Flow measuring devices such as irrigation water meters, flumes, weirs or other water measuring devices are usually installed in irrigation water ways to determine and control the rate and amount of irrigation water in a planned and efficient manner (EPA, 2003). However, it has been reported that such water measuring devices installed on irrigation projects in Ghana are hardly used to the advantage of the projects, making irrigation efficiencies of such projects difficult to determine (Kyei-Baffour and Ofori, 2006). The use of such water measuring devices involves complex mathematical formulae which are not suitable for water bailiffs on the Ghanaian irrigation projects. The manufacturers of such devices provide calibration curves to be used to determine the volumetric flow of water; however, these were not provided to the Bontanga irrigation at the time of construction of the project as revealed during this research.

Discussion of irrigation water management cannot exclude sediment inflow into irrigation reservoirs caused by runoff in the catchment. This is because sediment deposition in reservoirs has the potential of changing the area-capacity relationship of water reservoirs thereby affecting their useful life (Mau and Christensen, 2000; Sharma and Sharma, 1997). Measurement of sediment inflow into reservoirs as a result of surface runoff is therefore core to effective irrigation water management.

This paper seeks to calibrate the water measuring devices (flumes) on the Bontanga Irrigation Project as that expose the challenges that confront water management practices on the project. The paper also analysed results of runoff estimation within the reservoir catchment and the associated sediment deposition into the reservoir as these two issues pose some challenges to water management of irrigation projects.

The Bontanga Irrigation Project started crop production in 1984 after its completion in 1983. The total irrigable area of the project was 570 hectares at completion and it currently caters for about 600 farmers and their dependants from 17 villages in the Tolon and Kumbungu Districts of the Northern Region (Agyingayure, 2001). The project reservoir has a catchment of $165 \mathrm{~km}^{2}$ with a maximum storage capacity of $25 \times 10^{6} \mathrm{~m}^{3}$ at a gauge level of $5.8 \mathrm{~m}$ and a minimum storage capacity of $5 \times 10^{6} \mathrm{~m}^{3}$ at a gauge level of $1.52 \mathrm{~m}$ at completion of the project (Agyingayure, 2001). The available water at full capacity at completion of the project was therefore $20 \times 10^{6} \mathrm{~m}^{3}$.

\section{CALIBRATION OF FLUMES ON THE RIGHT AND LEFT BANK} MAIN CANALS

A current meter which is appropriate for velocity determination in open channel (Schwab et al, 1993) was used to determine the velocity of the flowing water at three different segments of the trapezoidal canals (see diagram in appendix) at the different water levels in the canals. In each segment the velocity is measured three times and the average calculated. The average velocity is multiplied by the segment cross sectional area to determine the discharge through the segment. The discharges through the three different segments are summed up to get the total discharge through the canal at any water level in the canal. The plots of the discharge against the water level in the canal for both canals are shown in figure 1 and figure 2 below. Based on the relationship between the discharge through the canals and the water levels in the canals, discharge tables as shown in table 3 and table 4 have been developed for use by the water bailiff or the farmers to facilitate the supply of actual amounts of water required at any time.

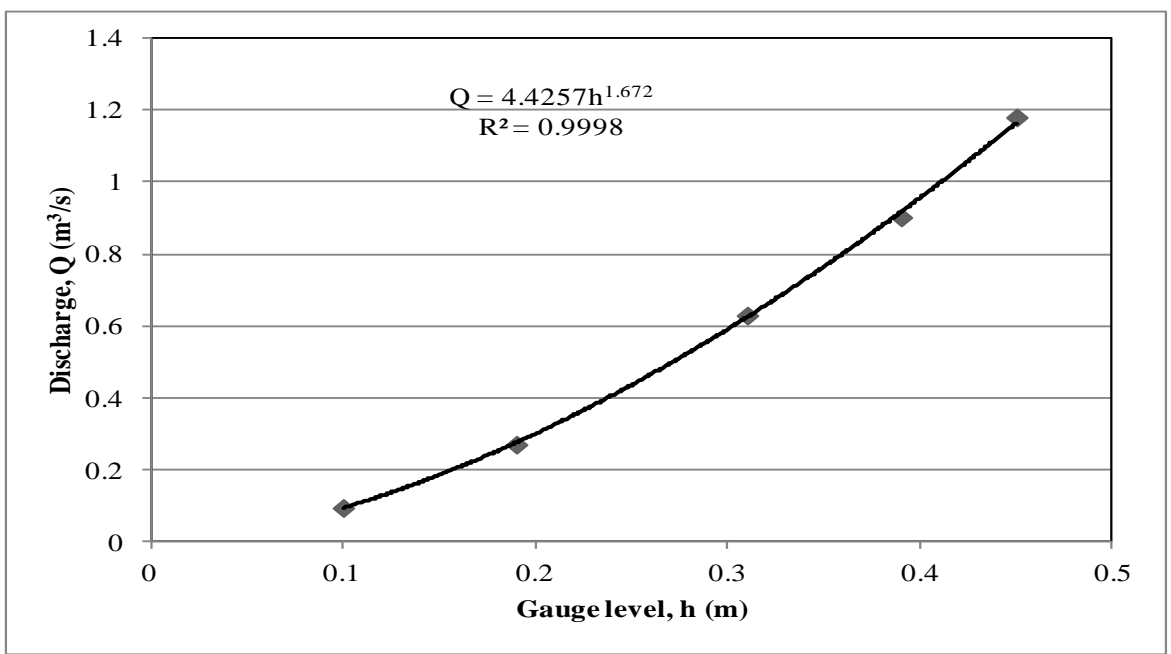

Figure 1: Gauge heights (h) against discharge (Q) for the right bank canal Table 3: Discharge table for the right bank canal 


\begin{tabular}{lcccccccccc}
\hline $\begin{array}{l}\text { Water } \\
\text { level, } \\
\mathbf{h}(\mathbf{m})\end{array}$ & $\mathbf{0 . 0 1 0}$ \\
\hline & $\mathbf{0 . 0 0}$ & $\mathbf{0 . 0 1}$ & $\mathbf{0 . 0 2}$ & $\mathbf{0 . 0 3}$ & $\mathbf{0 . 0 4}$ & $\mathbf{0 . 0 5}$ & $\mathbf{0 . 0 6}$ & $\mathbf{0 . 0 7}$ & $\mathbf{0 . 0 8}$ & $\mathbf{0 . 0 9}$ \\
$\mathbf{0 . 0}$ & 0.0000 & 0.0020 & 0.0064 & 0.0126 & 0.0203 & 0.0296 & 0.0401 & 0.0519 & 0.0649 & 0.0740 \\
$\mathbf{0 . 1}$ & 0.0942 & 0.1105 & 0.1278 & 0.1460 & 0.1653 & 0.1855 & 0.2067 & 0.2287 & 0.2517 & 0.2755 \\
$\mathbf{0 . 2}$ & 0.3001 & 0.3256 & 0.3520 & 0.3791 & 0.4071 & 0.4359 & 0.4654 & 0.4957 & 0.5268 & 0.5586 \\
$\mathbf{0 . 3}$ & 0.5912 & 0.6245 & 0.6586 & 0.6933 & 0.7288 & 0.7650 & 0.8019 & 0.8395 & 0.8778 & 0.9167 \\
$\mathbf{0 . 4}$ & 0.9564 & 0.9967 & 1.0377 & 1.0793 & 1.1216 & 1.1645 & 1.2081 & 1.2524 & 1.2972 & 1.3427 \\
$\mathbf{0 . 5}$ & 1.3889 & 1.4356 & 1.4820 & 1.5310 & 1.5796 & 1.6288 & 1.6786 & 1.7290 & 1.7800 & 1.8317 \\
$\mathbf{0 . 6}$ & 1.8839 & 1.9367 & 1.9900 & 2.0440 & 2.0985 & 2.1536 & 2.2093 & 2.2656 & 2.3224 & 2.3798 \\
$\mathbf{0 . 7}$ & 2.4377 & 2.4962 & 2.5553 & 2.6149 & 2.6751 & 2.7358 & 2.7971 & 2.8589 & 2.9212 & 2.9841 \\
$\mathbf{0 . 8}$ & 3.0475 & 3.1115 & 3.1760 & 3.2410 & 3.3066 & 3.3726 & 3.4392 & 3.5064 & 3.5740 & 3.6422 \\
$\mathbf{0 . 9}$ & 3.7109 & 3.7801 & 3.8498 & 3.9200 & 3.9907 & 4.0620 & 4.1337 & 4.2060 & 4.2787 & 4.3520 \\
\hline
\end{tabular}

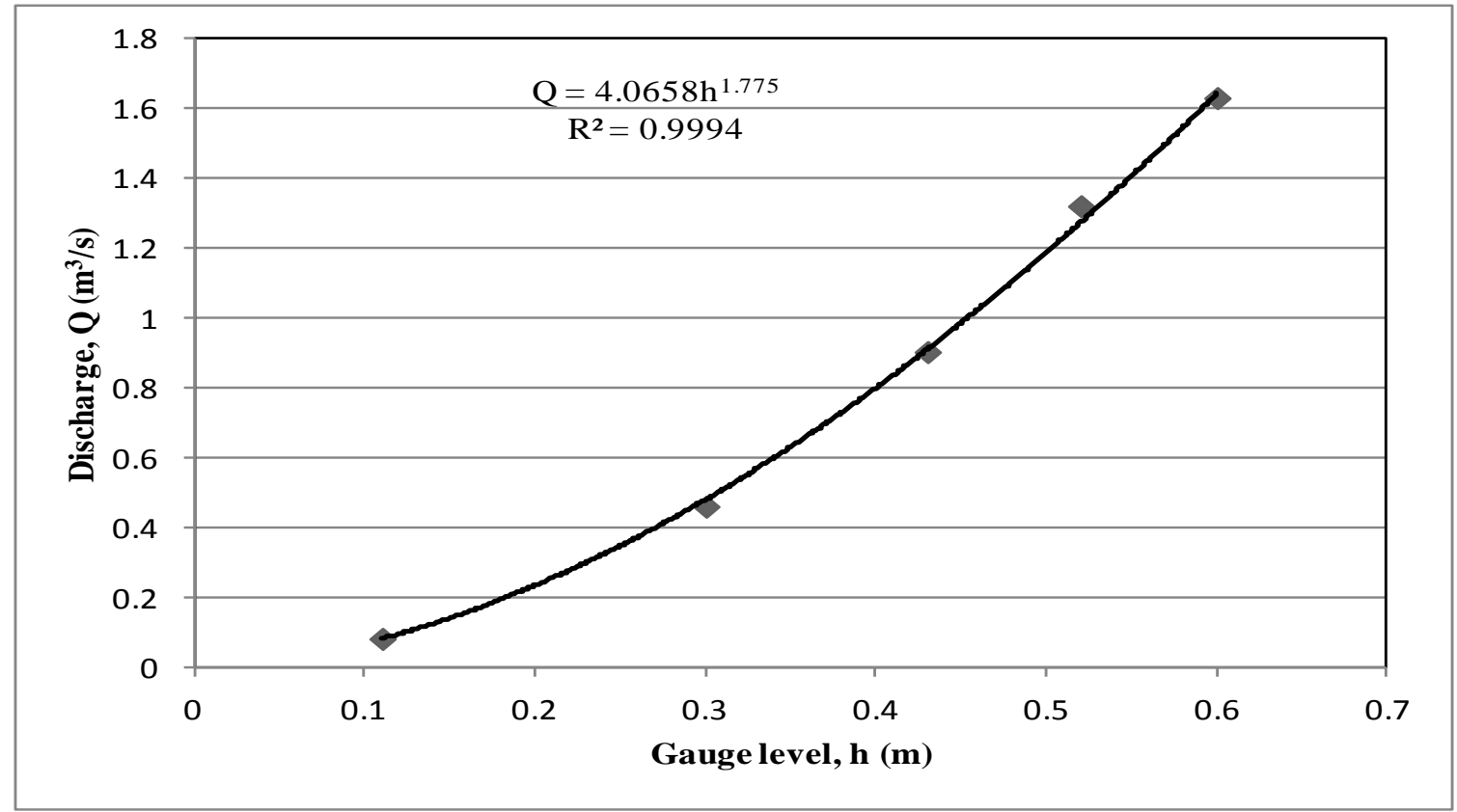

Figure 2: Gauge heights (h) against discharge (Q) for the left bank canal

Table 4: Discharge table for the left bank canal

\begin{tabular}{|c|c|c|c|c|c|c|c|c|c|c|}
\hline \multirow{2}{*}{$\begin{array}{l}\text { Water } \\
\text { level, } \\
\text { h (m) }\end{array}$} & \multicolumn{10}{|c|}{ Discharge through canal, $\mathrm{Q}\left(\mathrm{m}^{3} / \mathrm{s}\right)$} \\
\hline & 0.00 & 0.01 & 0.02 & 0.03 & 0.04 & 0.05 & 0.06 & 0.07 & 0.08 & 0.09 \\
\hline 0.0 & 0.0000 & 0.0011 & 0.0039 & 0.0081 & 0.0134 & 0.0199 & 0.0276 & 0.0362 & 0.0459 & 0.0566 \\
\hline 0.1 & 0.0683 & 0.0808 & 0.0943 & 0.1087 & 0.1240 & 0.1402 & 0.1572 & 0.1751 & 0.1938 & 0.2133 \\
\hline 0.2 & 0.2336 & 0.2547 & 0.2767 & 0.2994 & 03229 & 0.3471 & 0.3722 & 0.3979 & 0.4245 & 0.4518 \\
\hline 0.3 & 0.4798 & 0.5085 & 0.5380 & 0.5682 & 0.5991 & 0.6308 & 0.6631 & 0.6962 & 0.7299 & 0.7643 \\
\hline 0.4 & 0.7995 & 0.8353 & 0.8718 & 0.9090 & 0.9468 & 0.9854 & 1.0246 & 1.0644 & 1.1050 & 1.1462 \\
\hline 0.5 & 1.1880 & 1.2305 & 1.2737 & 1.3175 & 1.3619 & 1.4070 & 1.4527 & 1.4991 & 1.5461 & 1.5937 \\
\hline 0.6 & 1.6420 & 1.6909 & 1.7404 & 1.7905 & 1.8413 & 1.8926 & 1.9446 & 1.9972 & 2.0505 & 2.1403 \\
\hline 0.7 & 2.1587 & 2.2138 & 2.2694 & 2.3256 & 2.3825 & 2.4399 & 2.4980 & 2.5566 & 2.6159 & 2.6757 \\
\hline 0.8 & 2.7361 & 2.7971 & 2.8587 & 2.9209 & 2.9836 & 3.0469 & 3.1109 & 3.1754 & 3.2404 & 3.3061 \\
\hline 0.9 & 3.3723 & 3.4391 & 3.5065 & 3.5744 & 3.6429 & 3.7120 & 3.7816 & 3.8518 & 3.9226 & 3.9939 \\
\hline
\end{tabular}

It is easier with the support of the discharge tables to determine the quantity of water to be supplied to the fields in a day knowing the irrigation time, and such directives are not above the comprehension of the water bailiff. The project staff and farmers have shown interest working with such figures as they indicated that of recent times the water level in the reservoir has not been reaching the maximum levels. They supported this claim with example that it has been long since the water spilled. There is these believe by the farmers that the 
water level in the reservoir is dwindling as the years go by and there is the need to begin to "take good care of the water in the reservoir".

\section{ESTIMATING RUNOFF IN THE RESERVOIR CATCHMENT}

Runoff coefficient which is the ratio of volume of stream flow above base flow to the volume of rainfall (Sharma and Sharma, 1997) was the approach used to estimate runoff in the Bontanga irrigation reservoir catchment area. This was achieved by establishing an experimental plot, $5 \mathrm{~m}$ by $5.5 \mathrm{~m}$ in a cultivated area within the catchment area of the reservoir. The boundaries of the plot were well checked such that water flows out of the field in only one direction through an outlet into a collection system made from a galvanised rectangular tank $150 \mathrm{~cm}$ long, $100 \mathrm{~cm}$ wide and $50 \mathrm{~cm}$ deep. The galvanised tank was buried at the lower end of the slope and the depth of water in the tank was measured and emptied anytime it rained. The volume of water collected over the plot was then extrapolated for the entire catchment area of the reservoir. Some assumptions were made in the determination of the surface runoff using the controlled plot. These are: (i) That the reservoir catchment area $\left(165 \mathrm{~km}^{2}\right)$ has not changed since the commencement of the project. (ii) That no subsurface recharge of the reservoir occurs. (iii) That the runoff is uniform and constant over the entire catchment area and therefore the runoff on the single experimental plot was representative of the entire catchment. (iv) The rainfall on the experimental plot was deemed to have fallen on the entire catchment area at the same time. The plot of runoff $(\mathrm{R})$ against rainfall $(\mathrm{P})$ is shown in figure 3 below.

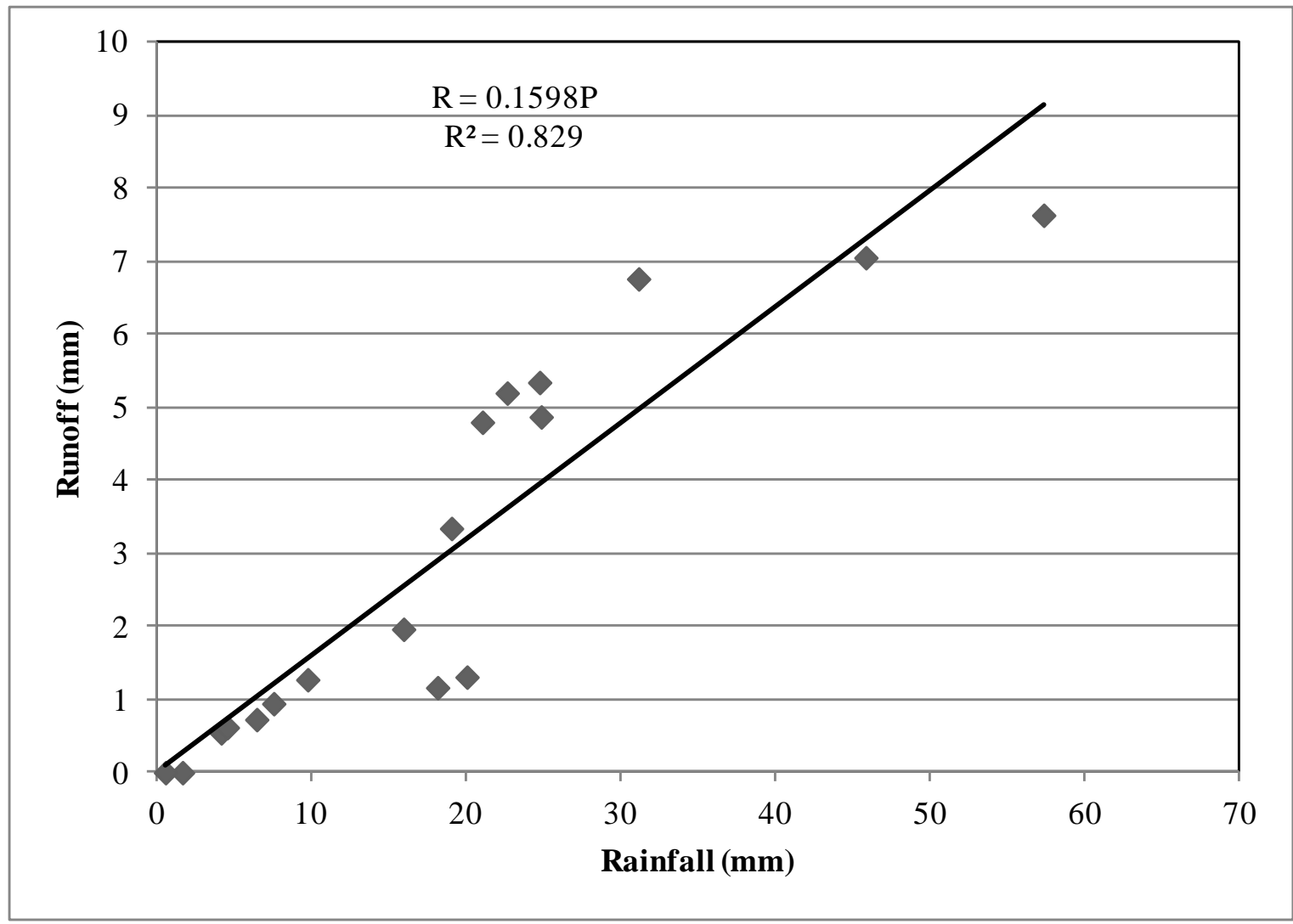

Figure 3: Runoff - Rainfall relationship

The runoff coefficient of 0.1598 shows that almost $16 \%$ of rainfall within the catchment area of the Bontanga irrigation reservoir goes into runoff. This figure is similar to what Stern and Longland (1993) estimated for the Volta Basin. The runoff go with it sediments into the reservoir as serious farming and other human activities are taking place within the catchment. Using this physical model established runoff volumes were computed over the catchment area and used to predict the reservoir capacity. In order to test the accuracy of the runoff - rainfall relationship the reservoir capacity was determined from the Area-Capacity curve provided to the Bontanga Irrigation Project by the consultants who supervised the construction of the project as observed capacity. It should be noted that in determining the predicted reservoir capacities the first previous reservoir capacity was assumed from the observed capacity and it was $11.63818 \times 10^{6} \mathrm{~m}^{3}$. 


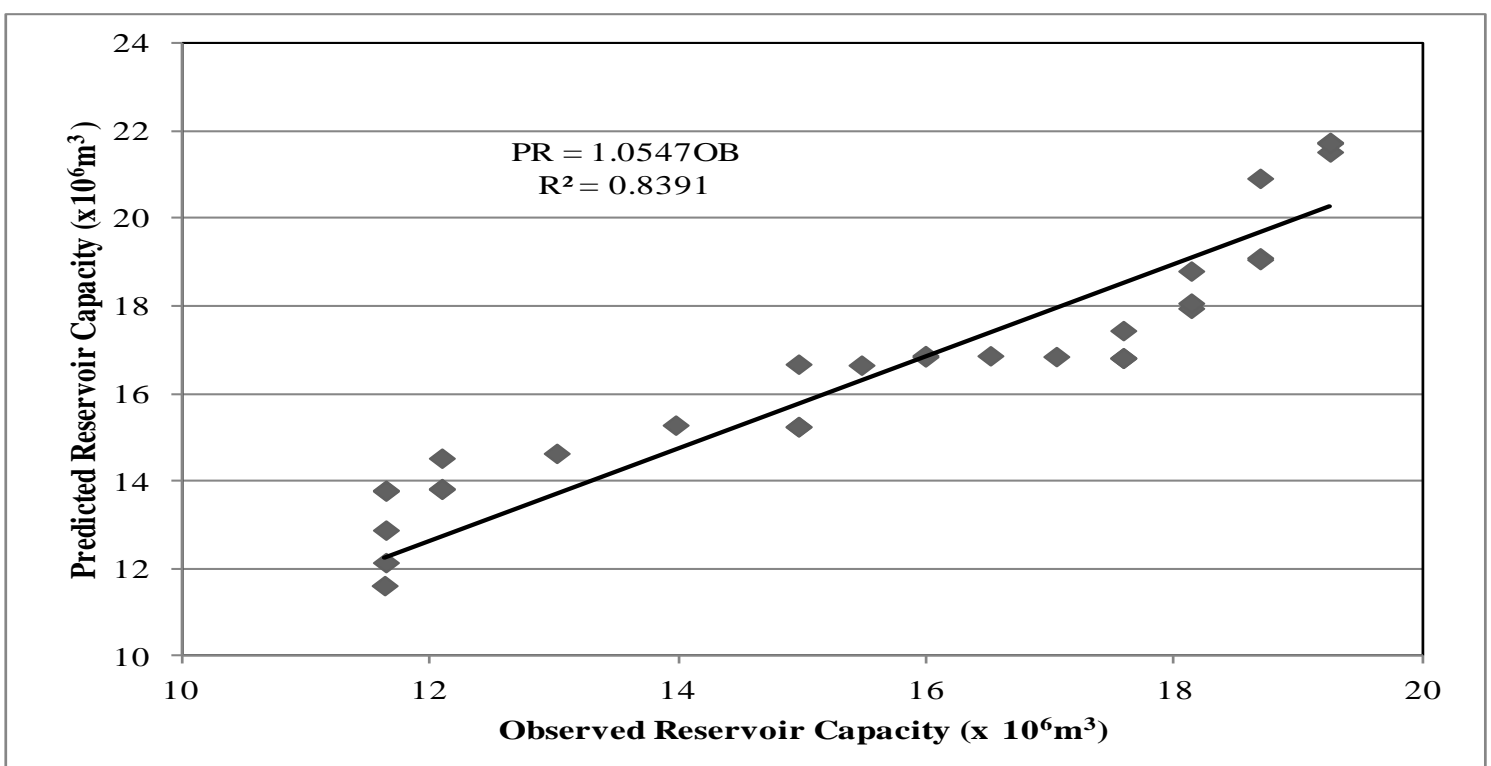

Figure 4: Predicted reservoir capacity against observed reservoir capacity

The relationship between the observed and predicted reservoir capacity $(\mathrm{PR}=1.0547 \mathrm{OB})$ suggest that there was an over prediction of the reservoir capacity by $5.47 \%$ suggesting that the assumptions made in the prediction are reasonable within the limits of experimental error.

\section{DETERMINATION OF SEDIMENT DEPOSITION IN THE RESERVOIR}

A coring device (Mau and Christensen, 2000) specially fabricated with the following dimensions: round pipe, two (2) centimetres diameter, and three (3) meters long was welded to a ten (10) centimetre diameter and $1.5 \mathrm{~m}$ long pipe. Whilst the ten (10) centimetre pipe was the actual coring device, the long pipe served as the means of reaching the bottom of the reservoir. The coring in the reservoir was achieved by using a boat on the water and with the help of fishermen paddling the boat to become still, sediment samples were taken at each of the intakes by hammering the coring device into the sediments till the hard core was reached. The coring device was then brought out of the water and the collected sediments gently removed and the height measured. This was repeated six times at each spot very close to each of the intakes. This data was collected in 2004 as part of the author's research for his MSc thesis. The results of the coring exercise are shown in table 5 below.

Table 5: Height of sediment deposited at the intakes of the Bontanga reservoir (1983-2004)

\begin{tabular}{|c|c|c|c|c|c|c|c|c|}
\hline & \multicolumn{6}{|c|}{$\begin{array}{l}\text { Height of sediment deposited around the } \\
\text { intakes within } 20 \text { years of operation }(\mathrm{m})\end{array}$} & \multirow{2}{*}{$\begin{array}{c}\text { Average } \\
\text { (m) }\end{array}$} & \multirow{2}{*}{$\begin{array}{c}\text { Estimated } \\
\text { deposit/year } \\
(\mathrm{cm})\end{array}$} \\
\hline & 1 & 2 & 3 & 4 & 5 & 6 & & \\
\hline Right bank intake & 1.30 & 1.34 & 1.34 & 1.30 & 131 & 1.33 & 1.32 & 6.60 \\
\hline Left bank intake & 1.27 & 1.28 & 1.28 & 1.27 & 1.26 & 1.26 & 1.27 & 6.35 \\
\hline
\end{tabular}

The reservoir of the Bontanga irrigation project which has been reported to have a dead storage height of $1.52 \mathrm{~m}$ (Agyingayure, 2001) to cater for any sediment inflow throughout the live of the reservoir was facing eminent danger as at 2004. This is because with the level of sediment deposition into the reservoir in less than four years from 2004, the reservoir may not be able to supply water to the canals for irrigation. It was refreshing when a follow up was made in 2013 to the project site revealed that in 2006 a diver was hired to clear sediment deposited around the two intakes when lower flow rates were being recorded.

\section{CONCLUSION}

The paper has shown that efficient and effective water management on irrigation projects in Ghana are confronted with some challenges and project managers must take the challenges seriously if the projects are to yield the desired results in both short and long terms. To ensure that water bailiffs, who are most of the time not having any formal education, are able to supply calculated amounts of water to the irrigation fields, the water measuring devices must be calibrated and discharge tables generated for the different water levels in the canals. As most of the irrigation projects depend on open reservoirs with human activities taking place in their catchment areas, effort must be put in to monitor sediment build up in the reservoirs as that poses danger to the life of the reservoirs and for that matter the irrigation projects. 
It is recommended that effective and efficient water management practices must be stepped up on the Bontanga Irrigation project and other projects if the country wants to derive the needed benefits from the project.

\section{REFERENCES}

[1] Agyingayure, V. (2001) Summary of pertinent data/information on Bontanga Irrigation Project. Project Report.

[2] Braimah, C. A. (2004) Water Balance Study of Bontanga Irrigation Reservoir and Some Environmental Issues. Kwame Nkrumah University of Science and Technology. (Unpublished MSc Thesis).

[3] Dinye, R. D. and Ayitio, J. (2013) Irrigated agricultural production and poverty reduction in Northen Ghana: A case study of the Tono Irrigation Scheme in the Kassena Nankana District. International Journal of Water Resources and Environmental Engineering Vol. 5(2), pp. 119-133.

[4] Environmental Protection Agency (EPA) (2003) National Management Measures to Control Nonpoint Pollution from Agriculture. Washington, USA.

[5] Faulkner, J. W. (2006) Water Use, Productivity, and Profitability of Small Scale Irrigation Schemes in Ghana's Upper East Region. Cornell University (Unpublished MSc Thesis)

[6] Gleick, P. H. (1992) The Effects of Climate Change on Shared Freshwater Resources. Cambridge University Press, Cambridge.

[7] Kyei-Baffour, N., Ofori, E. (2006) Irrigation Development and Management in Ghana: Prospects and Challenges. Journal of Science and Technology Vol. 26(2) pp 148 - 159.

[8] Mau, D. P. and Christensen, V. G. (2000) Comparison of Sediment Deposition in Reservoirs

[9] of Four Kansas Watersheds. Kansas Water Science Center. U. S. Geological Survey. Available online at: http://ks.water.usgs.gov/pubs/fact-sheets/fs.102-00.pdf (Accessed on 5th February, 2014)

[10] Ministry of Food and Agriculture (MoFA) (2013) Ghana Irrigation Development Authority. Brief profile of Irrigation Development Authority. Available online at: http://mofa.gov.gh/site/?page_id=2976 (Accessed on 30 ${ }^{\text {th }}$ January 2014)

[11] Ministry of Food and Agriculture (MoFA) (2011) National Irrigation Policy, Strategies and Regulatory Measures. Irrigation Development Authority. Accra.

[12] Miyoshi, T., Nagayo, N (2006) A Study of the Effectiveness and Problems of

[13] JICA's Technical Cooperation from a Capacity Development Perspective: Case Study of Support for the Advancement of Ghana's Irrigated Agriculture. Institute for International Cooperation. Japan International Cooperation Agency (JICA).

[14] Namara, R. E., Horowitz, L., Kolavalli, S., Kranjac-Berisavljevic, G., Dawuni, B. N., Barry, B. and Giordano, M. (2010) Typology of Irrigation Systems in Ghana. IWMI Working Paper 142

[15] Schwab, G. O.; Fangmeier, D. D.; Elliot, W. J.; Frevert, R. K. (1993) Soil and Water Conservation Engineering. Hamilton Printing Company, USA.

[16] Sharma, R. K. and Sharma, T. K. (1997) A textbook of Hydrology and Water Resources Engineering. Dhanpat Rai Publications Ltd, New Delhi.

[17] Stern, P. and Longland, F. (1993) Field engineering: an introduction to development work and construction in rural areas. Intermediate Technology Publication Ltd, UK.

\section{APPENDIX}

1. Velocity measurements through the right bank main canal at the different sections and different water levels.

\begin{tabular}{|c|c|c|c|c|c|c|c|c|c|c|c|c|c|}
\hline \multirow{3}{*}{ No. } & \multirow{3}{*}{$\begin{array}{l}\text { Gauge } \\
\text { reading } \\
(\mathrm{cm})\end{array}$} & \multicolumn{12}{|c|}{ Velocity $(\mathrm{m} / \mathrm{s})$ of flow using current meter } \\
\hline & & \multicolumn{4}{|c|}{ Section 1} & \multicolumn{4}{|c|}{ Section 2} & \multicolumn{4}{|c|}{ Section 3} \\
\hline & & 1 & 2 & 3 & Av. & 1 & 2 & 3 & Av. & 1 & 2 & 3 & Av. \\
\hline 1 & 10 & 0.462 & 0.450 & 0.456 & 0.456 & 0.527 & 0.539 & 0.531 & 0.532 & 0.308 & 0.285 & 0.302 & 0.298 \\
\hline 2 & 19 & 0.603 & 0.641 & 0.614 & 0.619 & 0.754 & 0.760 & 0.782 & 0.765 & 0.520 & 0.597 & 0.554 & 0.557 \\
\hline 3 & 31 & 0.826 & 0.810 & 0.809 & 0.815 & 0.998 & 1.004 & 1.045 & 1.016 & 0.861 & 0.844 & 0.824 & 0.843 \\
\hline 4 & 39 & 0.862 & 0.866 & 0.840 & 0.856 & 1.149 & 1.144 & 1.087 & 1.127 & 0.872 & 0.855 & 0.825 & 0.851 \\
\hline 5 & 45 & 1.043 & 1.037 & 0.995 & 1.025 & 1.177 & 1.240 & 1.237 & 1.218 & 1.055 & 1.005 & 1.011 & 1.024 \\
\hline
\end{tabular}

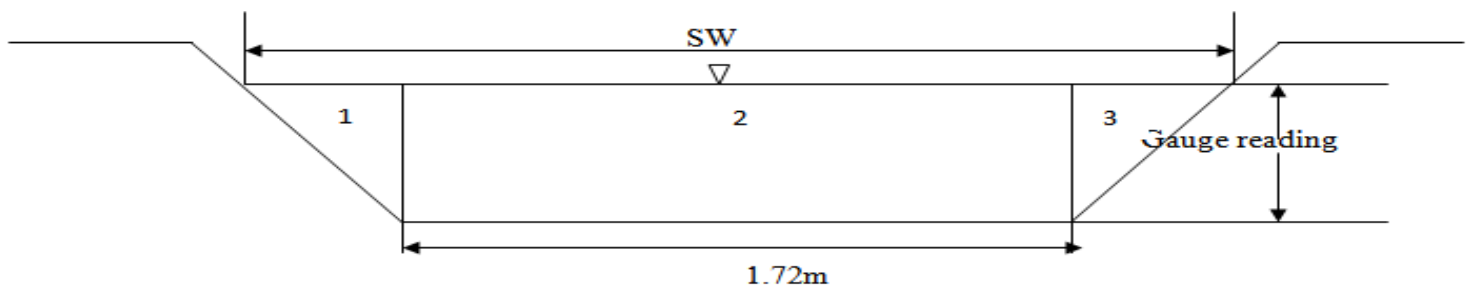


2. Velocity measurements through the left bank main canal at the different sections and different water levels.

\begin{tabular}{|c|c|c|c|c|c|c|c|c|c|c|c|c|c|}
\hline \multirow{3}{*}{ No. } & \multirow{3}{*}{$\begin{array}{l}\text { Gauge } \\
\text { reading } \\
\text { (cm) }\end{array}$} & \multicolumn{12}{|c|}{ Velocity $(\mathrm{m} / \mathrm{s})$ of flow using current meter } \\
\hline & & \multicolumn{4}{|c|}{ Section 1} & \multicolumn{4}{|c|}{ Section 2} & \multicolumn{4}{|c|}{ Section 3} \\
\hline & & 1 & 2 & 3 & Av. & 1 & 2 & 3 & Av. & 1 & 2 & 3 & Av. \\
\hline 1 & 11 & 0.410 & 0.407 & 0.372 & 0.396 & 0.443 & 0.426 & 0.447 & 0.414 & 0.327 & 0.348 & 0.307 & 0.391 \\
\hline 2 & 30 & 0.728 & 0.724 & 0.731 & 0.728 & 0.773 & 0.749 & 0.730 & 0.751 & 0.759 & 0.742 & 0.738 & 0.746 \\
\hline 3 & 43 & 0.871 & 0.863 & 0.838 & 0.857 & 0.998 & 990 & 0.980 & 0.989 & 0.847 & 0.874 & 0.864 & 0.862 \\
\hline 4 & 52 & 1.105 & 1.095 & 1.085 & 1.095 & 1.117 & 1.112 & 1.115 & 1.115 & 1.070 & 1.077 & 1.078 & 1.075 \\
\hline 5 & 60 & 1.115 & 1.162 & 1.173 & 1.150 & 1.199 & 1.189 & 1.154 & 1.163 & 1.149 & 1.145 & 1.153 & 1.149 \\
\hline
\end{tabular}

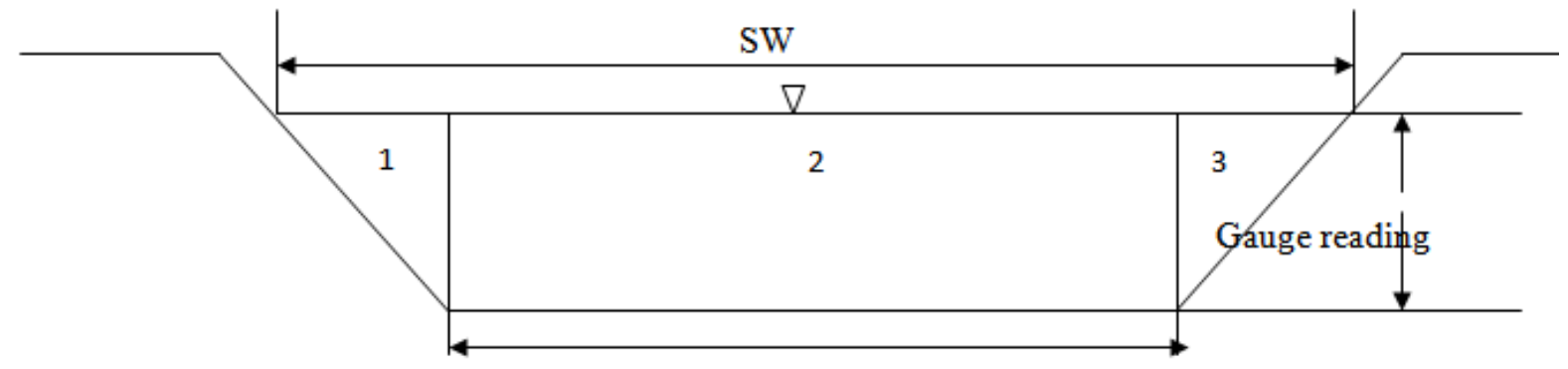

$1.72 \mathrm{~m}$ 